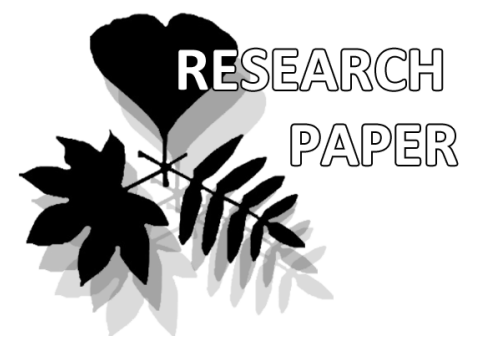

Maria V. Tekleva

e-mail: tekleva@mail.ru

A.A. Borissiak Paleontological Institute, Russian Academy of Sciences, Moscow 117647 Russia

Manuscript received: 07.08.2015

Review completed: 15.09.2015

Accepted for publication: 01.10.2015

Published online: 20.10.2015

\section{Bisaccate Pollen of Probable Gnetalean Species and Pollen Diversity in Gnetophytes}

\author{
Maria V. Tekleva
}

\begin{abstract}
A B S T R A C T
The exine ultrastructure of Dinophyton spinosum (Upper Triassic, USA), Preflosella nathania, and Alisporites alimentosus (Lower Cretaceous, Russia) has been studied. Pollen grains were extracted from reproductive organs of Dinophyton spinosum and Preflosella nathania; pollen grains of Alisporites alimentosus are from the guts of a fossil insect. Dinophyton and Preflosella are attributed to gnetophytes, Alisporites alimentosus pollen grains were supposed to be produced by Preflosella plant.The infratectum is alveolate in the three species; however, the alveola pattern and thickness of the layers are condiserably different. Therefore, Alisporites alimentosus and Preflosella nathania are not closely related. Bisaccate alveolate pollen grains are distinct from other known pollen types of gnetophytes (non-saccate, granular or columella-like). Gnetophytes share certain pollen types with other plant groups; their comparison and possible transitions between gnetalean pollen types are discussed.
\end{abstract}

K e y w o r d s : Dinophyton, Preflosella, Alisporites, gnetophytes, exine ultrastructure

\section{P E 3 Ю M E}

Теклева М.В. Авумешковый морфотип возможных гнетовых и разнообразие пыльцевых зерен гнетофитов. Изучена ультраструктура экзины Dinophyton spinosum (верхний триас, США), Preflosella nathania и Alisporites alimentosus (нижний мел, Россия). Пыльцевые зерна Dinophyton spinosum и Preflosella nathania были извлечены из соответствующих репродуктивных органов; пыльцевые зерна Alisporites alimentosus извлечены из отпечатка желудка ископаемого насекомого. Dinophyton и Preflosella относят к гнетофитам. ПреАполагалось, что пыльцевые зерна Alisporites alimentosus продуцировались Preflosella. Эти три вида характеризуются ячеистым инфратектумом, однако характер ячеистости и толщина слоев значительно различаются у этих виАов. Таким образом, показано, что пыльцевые зерна Alisporites alimentosus не могли продуцироваться Preflosella nathania. Авумешковые ячеистые пыльцевые зерна Dinophyton и Preflosella отличаются от остальных известных пыльцевых типов гнетофитов (безмешковые, с гранулярным или столбиковиАным инфратектумом). Пыльцевые типы гнетофитов встречаются также в Аругих группах растений; рассмотрены сравнение и возможные переходы межАу пыльцевыми типами гнетофитов.

К $\mathbf{~ ю ~ ч е ~ в ~ ы ~ е ~ с ~} \mathbf{о}$ в а: Dinophyton, Preflosella, Alisporites, гнетофиты, ультраструктура экзины

\section{N T ROD UCT IO N}

Despite existing and lasting studies, gnetophytes still remain an enigmatic group without a definite classification. The diversity in the structure of macroremains and pollen makes it a difficult task. At least seven groups can be outlined among their pollen according to the aperture type, general morphology and general infratectal type of the exine. But within each of these groups greater diversity can be found, especially at the level of sporoderm ultrastructure (Tekleva \& Krassilov 2009). There is no group like gnetophytes that comprises such a wide range of morphological and ultrastructural diversity of its members. The relationship of gnetophytes with other seed plants plays a key role in understanding the evolution of gymnosperms and angiosperms as gnetophytes show a striking combination of features characterizing the two. So it is particularly important to document in detail all the characters for each taxon for a comprehensive comparison.

In this paper the exine ultrastructure of three species, Dinophyton spinosum Ash, Preflosella nathania Krassilov, and Alisporites alimentosus Krassilov, is described for the first time. The photos of these pollen of SEM can be seen in Tekleva \& Krassilov (2009); there is also a short review on pollen diversity of gnetophytes, including these three species. The three species are characterized by typically conifer bisaccate pollen, but pollen grains of Dinophyton spinosum and Preflosella nathania were found in situ in reproductive structures showing some gnetalean features (Krassilov \& Ash 1988, Krassilov 1997, Krassilov \& Bugdaeva 1999). Pollen grains of Alisporites alimentosus are similar in morphology to those 
of Preflosella nathania, and had been found by Krassilov \& Rasnitsyn (1982) in an insect gut from the same locality as Preflosella. The two findings were supposed to belong to the same genus (Krassilov \& Bugdaeva 1999). The data on the exine structure of Alisporites alimentosus are described and discussed here in this context. The studied pollen morphology and ultrastructure are considered in light of pollen diversity of gnetophytes.

\section{MATERIAL AND METHODS}

Pollen grains were extracted from the compressions of the reproductive structures (Preflosella nathania Krassilov, Lower Cretaceous Baisa locality, Transbaikalia, Russia - Krassilov \& Bugdaeva 1999), Dinophyton spinosum Ash Upper Triassic Chinle Formation of Arizona, USA - Krassilov \& Ash 1988) or guts of insects (Alisporites alimentosus Krassilov, Lower Cretaceous Baisa locality, Transbaikalia, Russia - Krassilov \& Rasnitsyn 1982).

Pollen grains of Preflosella nathania and Alisporites alimentosus were macerated with Schulze solution and alkali. Pollen grains of Dinophyton spinosum were extracted from the glycerin-gelatine slides (given by Prof. V.A. Krassilov), and washed in hot water and acetone.

Cleaned pollen grains were fixed with $1 \%$ $\mathrm{OsO}_{4}$, dehydrated in an ethanol series, stained with uranyl acetate, dehydrated in acetone, and embedded in epoxy resin according to MeyerMelikian et al. (2004) for transmission electron microscopy (TEM). Pollen grains were sectioned with an ultramicrotome LKB-3. The ultrathin sections were post-stained with lead citrate and examined under Jeol 100B and Jeol 400 TEMs at the laboratory of electron microscopy, Biological faculty, Lomonosov Moscow State University.

\section{R E S U LT S}

\section{Dinophyton spinosum Ash, 1970 (Fig. 1)}

Dinophyton spinosum was described from the Upper'Triassic depostis of the USA (Ash 1970). Pollen organs from the Late Triassic Chinle Formation of Arizona were later described and attributed to D. spinosum on the basis of the cuticular features and peculiar pubescence (Krassilov \& Ash 1988). Pollen grains extracted from the pollen organs are bisaccate, about $88 \times 45 \mu \mathrm{m}$, with the sacci $12.5-25 \mu \mathrm{m}$ wide. The sculpture in SEM is scabrate or indistinclty verrucose-foveolate, the sacci show coarse recitulations and folds. A leptoma is seen in LM. The pollen grains were compared with Alisporites- or Pteruchipollenites-type pollen grains (Krassilov \& Ash 1988).

The ectexine consists of a homogeneous tectum, alveolate

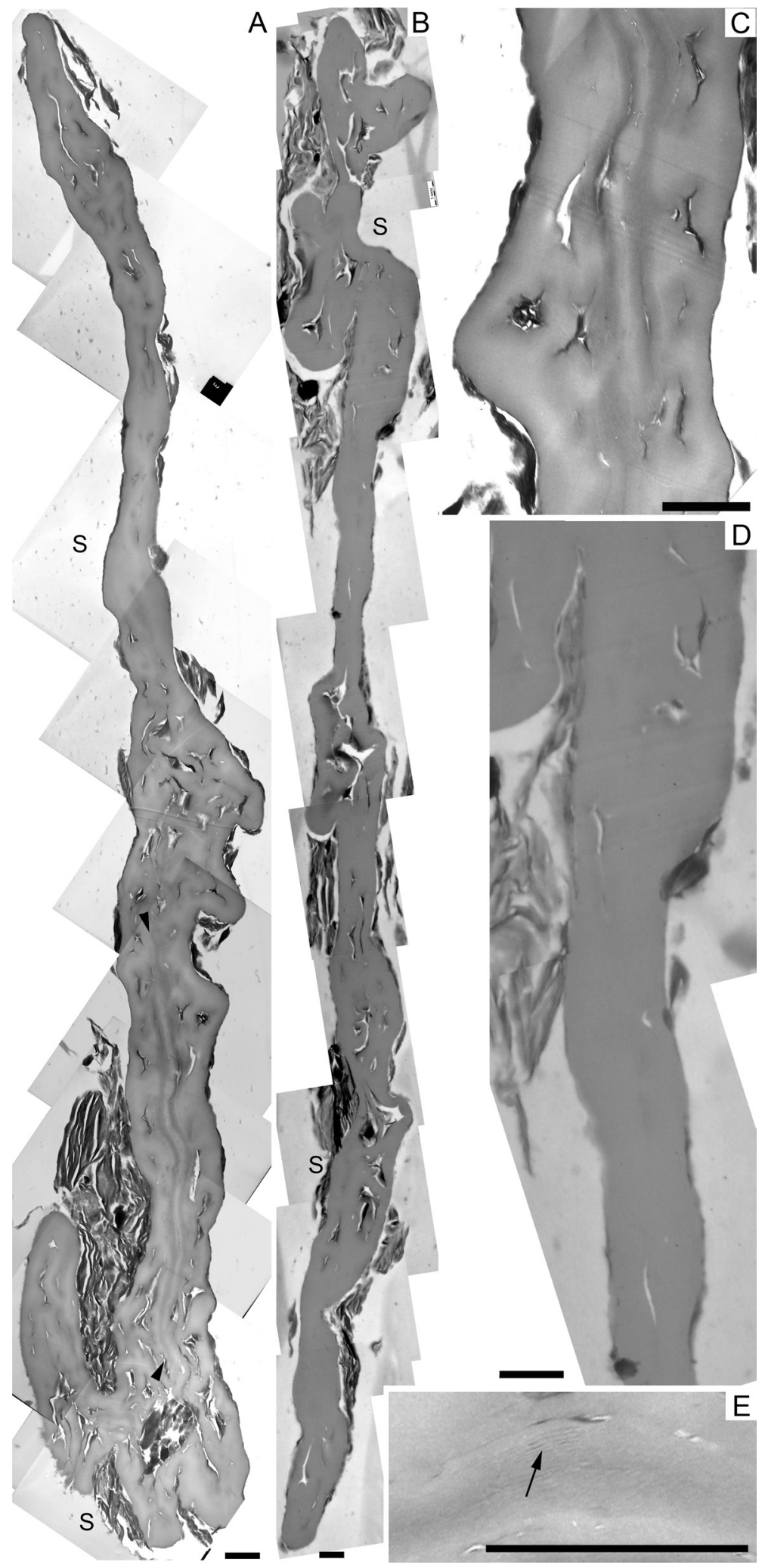

Figure 1 Exine ultrastructure of Dinophyton spinosum Ash, TEM. A, B - sections through the whole pollen grain, $\mathrm{S}$ - saccus, arrowheads borders the pollen body, $\mathrm{C}$ - non-apertural region of the pollen body; D - the region toward leptoma; E details of endexine, arrow indicates fine lamellations. Scale bars: $3.67 \mu \mathrm{m}$ - for A; $1 \mu \mathrm{m}$ - for B, D; $0.26 \mu \mathrm{m}-$ for $\mathrm{C}, \mathrm{E}$

infratectum, and relatively thin foot layer (Fig. 1A, B, C). The tectum is imperforate, with even surface, but of uneven thickness (from 0.3 to $0.7 \mu \mathrm{m}$ ). The infratectum is repre- 
sented by alveolae situated in one row and appears as a columella-like structure (Fig. 1C, D). Alveola walls are from 0.2 to $0.9 \mu \mathrm{m}$ thick, they are thicker in the cappa and cappula regions, than in the saccus region. The foot layer is from 0.2 to $0.5 \mu \mathrm{m}$ thick, homogeneous (Fig. 1C). The ectexine thickness increases at the cappa/ saccus border, the infratectum becomes distinctly alveolate, the saccus cavity is strongly compressed and the alveola arrangement is hard to describe (Fig. 1A, B). In the saccus region the ectexine is represented by the unevenly thickened tectum, alveolate infratectum and, probably, by the foot layer. There is a slightly less electron dense layer under the foot layer which might represent endexine. Its structure is homogenized but fine lamellations are seen at places (Fig. 1E). The apertural region is represented by the thin foot layer and possible endexine (Fig. 1D).

\section{Preflosella nathania Krassilov, 1999 (Fig. 2)}

The genus Preflosella with the so far sole species P. nathania (Krassilov \& Bugdaeva 1999) from the Baisa locality (Transbaikalia, Early Cretaceous) was described on the flower-like structure with a single whorl of perianth-like triangular bracts, with sporangial heads on thin axes, and with an ovuliferous cupule on the receptacle. Pollen grains extracted from the sporangia are bisaccate, with the long (equatorial) axis from 55 to $100 \mu \mathrm{m}$, the sacci are described as protosaccate. The cappa is broadly elliptical, minutely pitted. The lepto$\mathrm{ma}$ is on the distal side, slit-like, often overlapped by the converging sacci (Krassilov \& Bugdaeva 1999).

The sporoderm is about $1.22-1.62 \mu \mathrm{m}$ in the cappa region (Fig. 2A). The ectexine includes homogeneous tectum, alveolate infratectum, and thin foot layer. The tectum is about $0.2 \mu \mathrm{m}$ thick, uniform in thickness with wavy surface. The infratectum is about $0.8-1.3 \mu \mathrm{m}$ thick with elongated branched alveolae, which are located in one or two rows. The alveola wall thickness is the same as that of the tectum (Fig. 2B, C). At the cappa/saccus border the ectexine reduces in thickness and the alveolae become smaller, with thicker walls and narrow gaps (Fig. 2A, B). In the saccus region the infratectum thickness increases up to $6.7 \mu \mathrm{m}$, the alveolae also increase in size, their gaps become two or three times larger, and the number or alveola rows increase too (Fig. 2A, B). The alveolae of the outer row are small, their hight and width are similar. The alveolae of the inner row/rows are much larger. There is a thin, about $0.16 \mu \mathrm{m}$, homogeneous layer under the alveolate infratectum. In the saccus region this layer is discontinuous and of uneven thickness (Fig. 2A, B). As it is of the same electron density as the tectum and infratectum I interpret this layer as a foot layer. The endexine is absent or not preserved. The ectexine thickness reduces sharply toward apertural regions, first the infratectum disappears, then the tectum, and the apertural region is represented by the probable foot layer only (Fig. 2C).

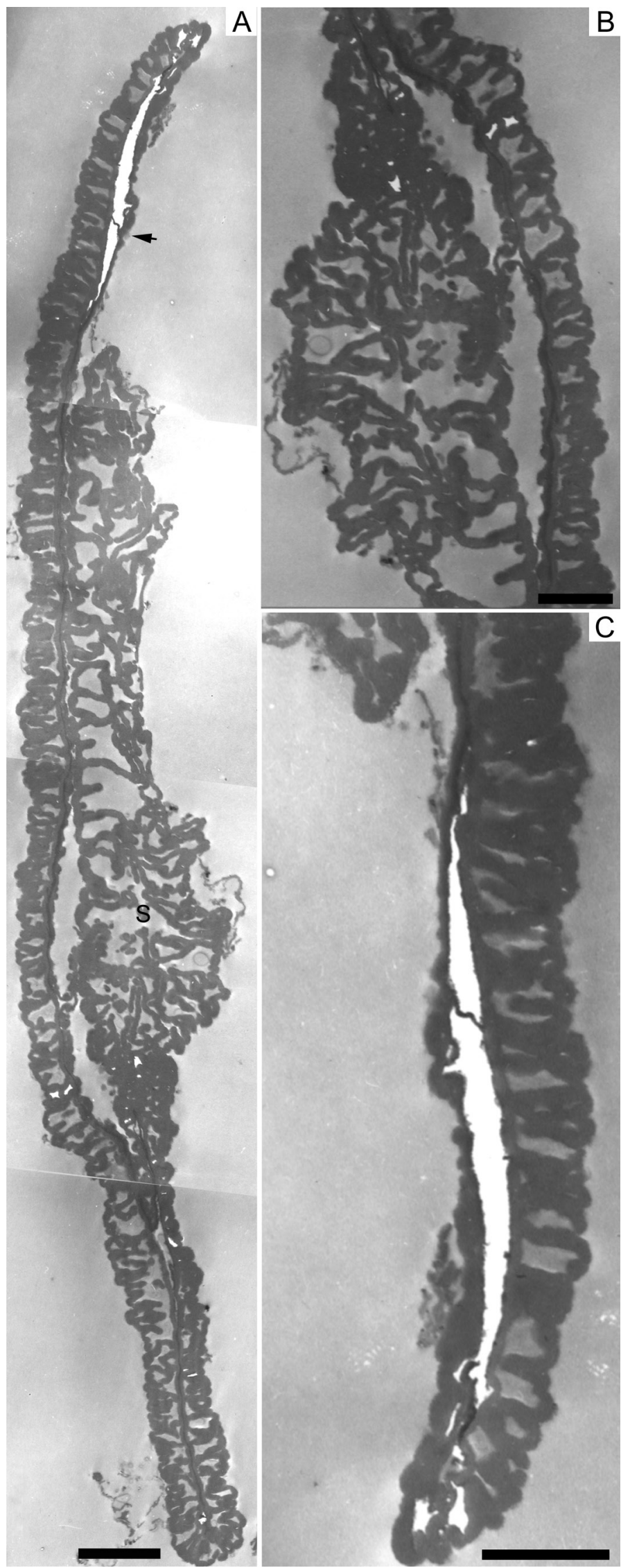

Figure 2 Exine ultrastructure of Preflosella nathania Krassilov, TEM. A section through the whole pollen, $\mathrm{S}$ - saccus, arrow indicates leptoma region, $\mathrm{B}$ - magnified saccus region (on the left), $\mathrm{C}$ - magnified leptoma region (on the left). Scale bars: $3.67 \mu \mathrm{m}-$ for $\mathrm{A}, 1.8 \mu \mathrm{m}-$ for $\mathrm{B}, \mathrm{C}$ 
Alisporites alimentosus Krassilov, 1982 (Fig. 3)

Pollen grains Alisporites alimentosus were described from the compression of guts of the xyelid species Anthoxyela anthophaga Rasn. in Krassilov \& Rasnitsyn (1982). Pollen grains are bisaccate, in the equatorial view the cappa contour smoothly lengthens to the saccus contour. The long axis is from 75 to $92 \mu \mathrm{m}$. The sculpture is verrucate with distinct verrucae on the cappa and cappula, and with flattened verrucae on the saccus surface. The leptoma can be bordered by ectexine folds, the leptoma membrane is scabrate (Krassilov \& Rasnitsyn 1982).

The ectexine consists of a thick homogeneous tectum, alveolate infratectum, and thin foot layer (Fig. 3A, B). The tectum is $0.6 \mu \mathrm{m}$ on average, imperforated, with even surface, but of uneven thickness (Fig. 3B). The infratectum is represented by one row of alveolae except for saccus regions. In the cappa region the infratectum hight gradually decreases and the sporoderm thickness is about $0.9 \mu \mathrm{m}$ (Fig. 3B). The foot layer is from $0.15 \mu \mathrm{m}$ to $0.3 \mu \mathrm{m}$ in different regions of the pollen grain, homogeneous. The ectexine thickness increases at the cappa/saccus border up to $1.17-1.5 \mu \mathrm{m}$, the infratectal alveolae are situated in two rows. The alveolae of the outer row are more or less isodiametric while the alveolae of the inner row is elongated with their hight about twice as large as their width. In the saccus region the ectexine is represented by the unevenly thickened tectum, alveolate infratectum about $3.6 \mu \mathrm{m}$ thick and clearly distinct foot layer. There is a large cavity about 3.6-4.5 $\mu \mathrm{m}$ thick between the infratectum and foot layer (Fig. 3B). The endexine is not well-preserved all over the pollen grain, of an uneven thickness, about $0.08-0.12 \mu \mathrm{m}$ when it is well-preserved. It is more electron dense than the ectexine, finely lamellate, the lamellae are tightly adpressed to each other, there are about ten of them (Fig. 3C). The ectexine gradually reduces in thickness toward apertural regions, the hight of the infratectal elements decreases, then they disappear, the tectum thickness decreases. The apertural region is represented by the endexine, foot layer and sometimes by individual sporopolleninous granules which most probably are remnants of the tectum (Fig. $3 \mathrm{~A}, \mathrm{~B})$. Orbicules and electron dense structures occur on the pollen surface (Fig. 3A, B).

\section{DISCUSSION}

\section{Comparison of the studied ultrastructures with literature data}

The studied pollen grains are similar in size; they are assignable to Alisporites-type by general morphology. The exine sculpturing is not conspicuous as to be an absolute distinguishing
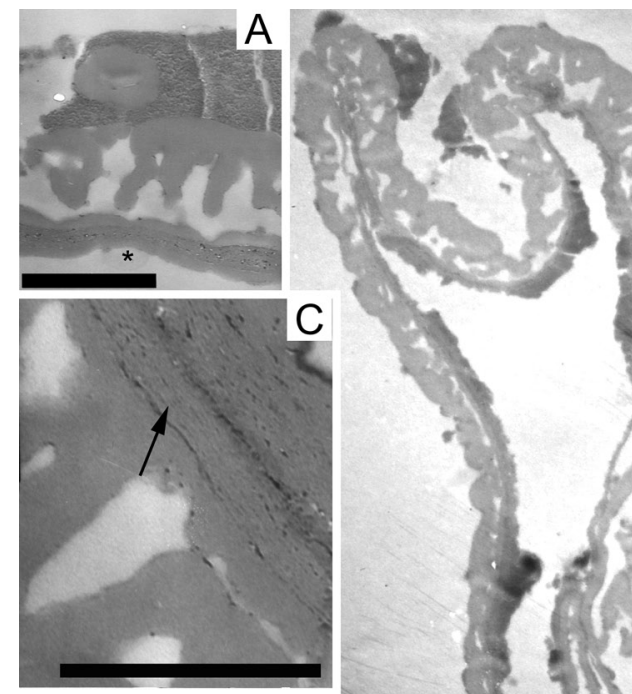

B

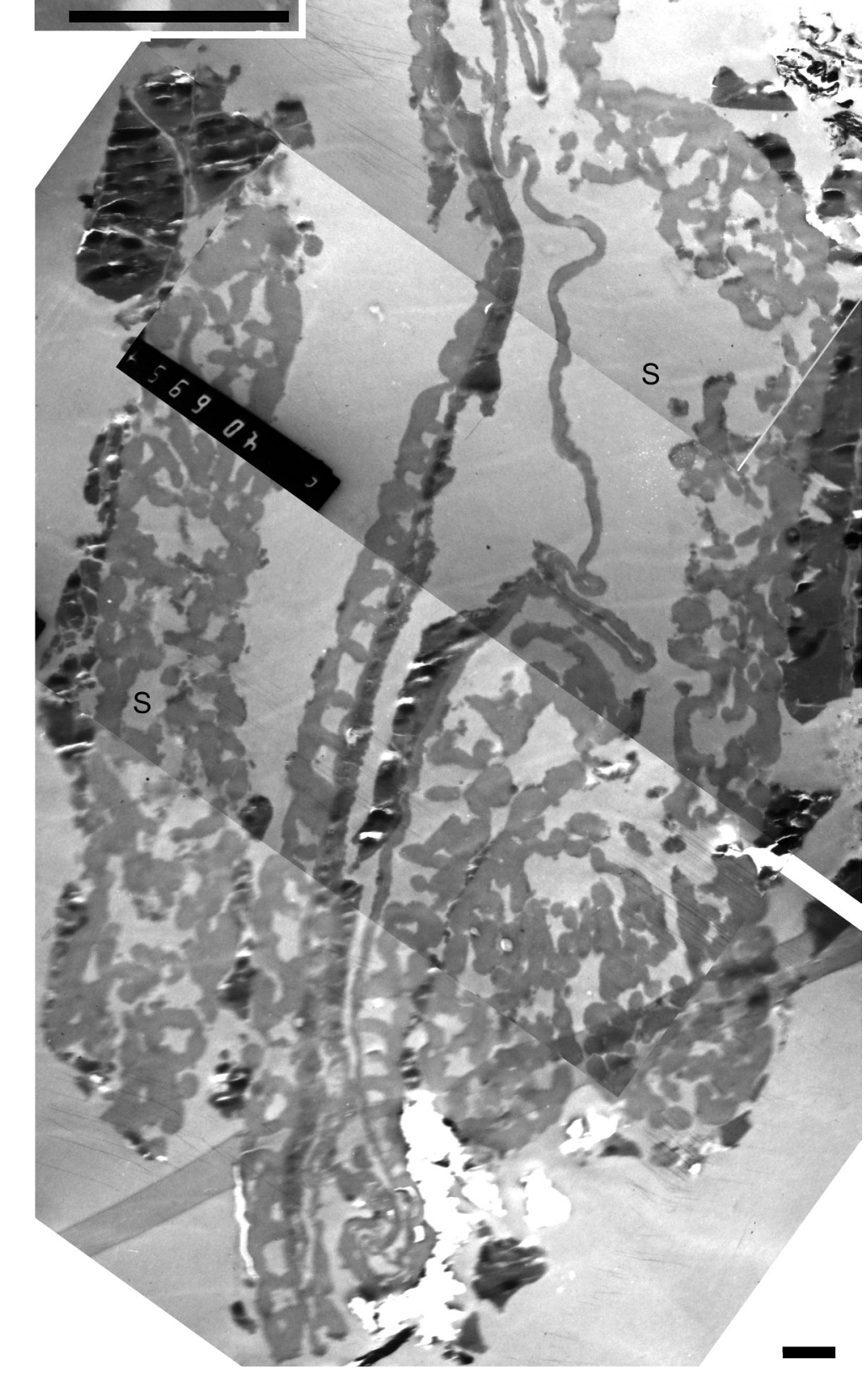

Figure 3 Exine ultrastructure of Alisporites alimentosus Krassilov, TEM. A - section of a pollen body part, leptoma region (asterisk) and orbicule are seen, $\mathrm{B}$ - section through the whole pollen, $\mathrm{S}$ - saccus, $\mathrm{C}$ - details of endexine, arrow indicate fine lamellations. Scale bars: $1 \mu \mathrm{m}-$ for A, C, $2.5 \mu \mathrm{m}-$ for B 
feature between the three species. In this paper I describe the exine ultrastructure and show that while pollen grains of Alisporites alimentosus, Dinophyton spinosum, and Preflosella nathania are characterized by the alveolate infratectum, the wall structure and alveola pattern are quite different between the three species. The main differences are the thickness of the tectum and alveola walls, as well as protosaccate versus eusaccate state. The accuracy of interpretation of the saccus state can depend on the preservation, temperature effects, electron microscopy preparation, endoreticulation nature and some other aspects (see discussion in Osborn \& Taylor, 1993, 1994). Here we consider pollen grains of Alisporites alimentosus as eusaccate and pollen grains of Preflosella nathania as protosaccate; Dinophyton spinosum has rather compressed exine and it is hard to be sure whether it was proto- or eusaccate.

The data on the exine ultrastructure of fossil saccate pollen are not abundant and most of the studied taxa come from Permian and Triassic deposits. Studies on Cretaceous saccate pollen are much less common. This empedes a consequent comparison of our pollen from the Baisa locality (Alisporites alimentosus and Preflosella nathania) with coeval pollen types. The deficit of ultrastructural data caused a comparative analysis of my results with available information on pollen material from the Triassic to Cretaceous.

\section{Dinophyton spinosum}

It is hard to make a comparison of the exine ultrastructure of Dinophyton spinosum due to the compressed state of the exine. However, the tectum and alveola walls are rather thick (robust) differring from many alveolate pollen. The exine ultrastructure can be at some extent compared with that of dispersed and in situ Protohaploxypinus (Zavialova 1998, Zavialova et al. 2001, Zavialova \& Karasev 2015), Caytonanthus pollen (Pedersen \& Friis 1986, Zavada \& Crepet 1986, Osborn 1994), and Arberiella pollen (Zavada 1991). Pollen grains from dispersed Arberiella sporangia studied by Zavada (1991) are of Protohaploxypinus-type, and this pollen type is characterized by the presence of several taenia on the proximal surface in contrast to Dinophyton pollen. Pollen grains extracted from Caytonanthus are much smaller that Dinophyton pollen.

Ash (1970) considered podocarpaceous Rissika media Townrow as a plant most similar to Dinophyton; Krassilov \& Ash (1988) concluded that Dinophyton might be seen as an evolutionary link between the Palaeozoic pteridosperms (Calamopityales) and extant gnetophytes. They also pointed out on a possible connection with corystosperms (Pteruchus). Taylor et al. (2009) note that Dynophyton could represent a member of a seed fern group but do not discuss it further. These comparisons of the macro remains do not help in further interpretation of Dynophyton pollen, as extant gnetophytes have non-saccate pollen with a granular infratectum, and Calamopityales species have spores. Pollen of Pteruchus is quite different from that of Dynophyton in having eusacci, thinner tectum and alveola walls.

There are several peculiar pollen organs from the Upper Triassic of the USA that are co-occuring with Dinophyton remains: an unnamed taxon described in Pigg et al. (1993), Creberanthus bealeii Axsmith et Ash (Axsmith \& Ash 2006), and two species of Pramelreuthia (Ash \& Litwin 1996). Ash and Litwin (1996) compared pollen extracted from Pramelreutbia yazzi Ash et Litwin and P. dubielii Ash et Litwin with Pityosporites and Protodiploxypinus respectively; therefore they differ from Dinophyton pollen. In situ pollen grains of Creberanthus bealeii and of an unnamed taxon described in Pigg et al. (1993) were of Alisporites-type and are very similar to Dinophyton pollen by general morphology. Unfortunately, only LM studies on these pollen grains have been done and we cannot make a further comparison.

\section{Preflosella nathania}

Pollen grains of Preflosella were considered similar to the Permotheca disparis (Zalessky) Naugolnykh morphotype (Krassilov \& Bugdaeva 1999). The exine ultrastructure of the two taxa differs considerably. The alveolae of Preflosella pollen are more elongated and their pattern changes toward the saccus region. Sacci are eusaccate in Permotheca, and protosaccate in Preflosella. The aperture region is represented by a lamellated endexine only in Permotheca, while the endexine in Preflosella is not preserved or absent and the aperture region consists of the foot layer. Caytonanthus pollen grains, another similar to Preflosella morphotype, are much smaller than the pollen under study. The exine ultrastructure of Caytonanthus (Zavada \& Crepet 1986, Pedersen \& Friis 1986, Osborn 1994) resembles that of Preflosella pollen. However, the latter differs in the infratectum structure in saccus regions by different alveola pattern, and hight and thickness of the infratectum. Besides, the endexine is reported for Caytonanthus pollen, but absent or not preserved in Preflosella pollen.

The exine ultrastructure of Preflosella pollen is quite similar to that of Pityosporites singularis Kedves (other species of the genus are much less similar, in particular in the alveola pattern) (Kedves 1994). However, there is a significant difference between the two species in the pattern of the lower alveola row in the saccus region: these alveolae are several times larger in pollen of Pityosporites singularis in comparison to pollen of Preflosella nathania.

Dispersed pollen grains of Scutasporites from Upper Permian deposits of the Kirov region, Russia, described in Zavialova (1998), show a remarkable similarity to Preflosella nathania pollen in the exine ultrastructure. The exine sculpturing and pollen size also correspond between the two. However, Preflosella pollen grains have a distinct foot layer, which is absent in Scutasporites pollen. Another difference is that Scutasporites pollen has three taenia. Gomankov \& Tarasevich (2012) studied the morphology and ultrastructure of pollen grains of Scutasporites nanuki Utting from Permian deposits of the Vologda region, Russia. The exine ultrastructure of this species is similar to Scutasporites studied by Zavialova (1998). They report that although the taenia of their pollen grains are not distinct in SEM, they are distinct in the ultrastructure. The taenia region comprises both tectum and infratectum, while the region between the taenia consists of the tectum only. Pollen grains of Preflosella nathania are not taeniate and the ultrastructure in the cappa region is uniform but otherwise the exine ultrastructure of Scutasporites pollen is most similar to that of Preflosella nathania among studied pollen so far. Pollen grains of Scutasporites-type are known 
from Dvinostrobus sagittalis Gomankov et Meyen sporangia associated with fructifications of Sachinia and leafy shoots of Quadrocladus (Gomankov \& Meyen 1986).

\section{Alisporites alimentosus}

Krassilov \& Rasnitsyn (1982) compared Alisporites alimentosus with Falcisporites and Picea sitchensis (Bongard) Carriere, though the latter is characterized by sacci shifted on the distal side. The only Falcisporites species was sectioned by Zavialova (1998) and shows a different exine ultrastructure. The exine ultrastructure of Picea species is also different especially in saccus regions (e.g., Meyer 1977, Pettitt 1985, Lazzaro 1999, Runions et al. 1999). Dispersed pollen grains of Alisporitestype were found in association with macro remains of the Corystospermaceae. Pollen grains extracted from corystospermaceous pollen organ Pteruchus were described by Townrow (1962, 1965), Osborn \& Taylor (1993), Xuanli et al. (1995), and Axsmith et al. (2000). The exine ultrastructure of Pteruchus pollen was studied by several authors (Taylor et al. 1984: P. dubius; Zavada \& Crepet 1985: P. africanus, P. dubius, and P. papillatus; Osborn \& Taylor 1993: Pteruchus sp.). The exine consists of a tectate imperforate ectexine and electron dense endexine. The ectexine includes a thin foot layer and an infratectum differently described (disrupted, probably alveolate infratectum in Taylor et al. 1984; irregularly shaped processes separated by lacunae in Zavada \& Crepet 1985; and alveolate in Osborn \& Taylor 1993). Unlike Pteruchus pollen, the studied pollen grains of Alisporites have a thicker foot layer, distinctly alveolate infratectum and lamellate endexine. The Alisporites pollen grains under study also differ in thicker exine in the cappa region.

Vesicaspora resembles Alisporites in having lamellate endexine, alveolate infratectum and similar ectexine ultrastructure in the cappa region (Millay \& Taylor 1974), but the alveola pattern in saccus regions is considerably different from that of Alisporites pollen. Further, Vesicaspora pollen grains (Callistophytales) are smaller and are characterized by bilocate monosulcate rather than bisaccate pollen. Vesicaspora pollen grains studied by Zavialova (1998) are even less similar to our Alisporites pollen differing in the ultrastructure of the cappa region.

Zavialova described a pollen grain (Zavialova 1998: \#36, Plates 6.1, 6.2) from Upper Permian deposits of Russia with an exine ultrastructure that is very similar to that of Alisporites alimentosus. Unfortunately, only one dispersed pollen grain was found and described and it is hard to make a reliable comparison. She believes that it shares some features with pollen of Caytonanthus and Piceapollenites but refrains from any attribution.

The exine ultrastructure of Alisporites alimentosus is notedly different from Caytonanthus (Pedersen \& Friis 1986, Osborn 1994, Zavada \& Crepet 1986) and Piceapollenites (Zavialova 1998, Zavialova et al. 2001) in its more regularly oriented alveolae, especially in the cappa region. Pollen grains of Alisporites-type were found in situ in some voltzialean plants (Taylor \& Grauvogel-Stamm 1995) but their exine ultrastructure is strikingly different from that of Alisporites alimentosus in alveola pattern.

\section{Pollen types of gnetophytes: which are they and which other plant groups share the same pollen types?}

Krassilov (2009) in his provisionary system of Gnetopsida divided it into two subclasses: Eugnetidae and Anthognetidae. Eugnetidae comprises following orders: Gnetales, Ephedrales, Welwitschiales, Fredlindiales, Heerales, and Cheirolepidiales. Anthognetidae comprises Dinophytonales, Axelrodiales, Eoanthales, and Baisiales.

Known data on pollen morphology of Gnetopsida members show that there is a great diversity of pollen characters. Among them the exine ultrastructure has been studied only for some of the members (see review in Tekleva \& Krassilov 2009). According to the grouped taxa within the orders there are:

- small microechinate inaperturate pollen (Gnetum) and small psilate/scabrate monosulcate pollen with vestigial sacci (Baisianthus) in Gnetales. The infratectal type is granular, mainly of small granules;

- small or medium-sized psilate polyplicate pollen, inaperturate (Ephedra-type) or with a distal sulcus (Welwitschia-type) in Ephedrales, Welwitschiales, Eoanthales. The infratectal type is granular, of small granules;

- small psilate/scabrate monosulcate (Loricanthus and Aegianthus) and trisulcate (Eucommiidites) pollen in Heerales. The infratectal type is granular (in some Eucommiidites) or columella-like;

- pollen grains of Classopollis-type in Cheirolepidiales. The infratectal type is granular or columella-like;

- large bisaccate pollen of Alisporites-type in Dinophytonales. The infratectal type is alveolate;

- ?large monosulcate non-saccate pollen in Baisiales.

The diversity of pollen characters in gnetophytes is amazing. Besides, there is a combination of gymnospermous (bisaccate pollen, alveolate infratectal type) and angiospermous (triaperturate pollen, columella-like infratectal type) features in different members of the group. The only example of similar pollen diversity within the same systematic group is represented in Peltaspermales. Bisaccate, bisaccate taeniate, non-saccate striate and non-saccate pollen grains are known for Peltaspermales members; Peltaspermales share some of these types with other plant groups (see review in Zavialova \& Van Konijnenburg-van Cittert 2011). Like gnetophytes, this is a rare case when such distinct types as saccate and non-saccate pollen occur within one systematic group (e.g., order). Below we discuss these pollen characters (saccate pollen, triaperturate pollen, alveolate and columella-like infratectal types) in light of their possible development in gnetophytes and their occurrence in other systematic groups.

\section{Saccate pollen and alveolate infratectum}

The studied Preflosella nathania and Dinophyton spinosum are the only ones so far with bisaccate pollen among gnetophytes and they compose the order Dinophytonales (Krassilov 2009). The exine ultrastructure of Preflosella nathania and Dinophyton spinosum is alveolate and this also makes a difference between them and other gnetophyte members. On the contrary, many conifer species are characterized by similar bisaccate alveolate pollen grains. According to the known data on the exine ultrastructure of Gnetopsida 
members the rest of the taxa is characterized by granular or columella-like infratectum. Probably, accumulating data will contribute to reveal transitional forms between gnetophyte members with different infratectal types or will show their development from several phylogenetic lines.

Pollen grains were reported from the same locality as Preflosella nathania and Alisporites alimentosus which might have been produced by gnetophytes. Pollen grains were found at the top of a nucellus of Baisia and reported to be alveolate (Krassilov \& Bugdaeva 1982), but no TEM study was done for these pollen. Besides, there is no certainty whether these pollen grains were produced by Baisia plant.

There is another pollen taxon with an alveolate infratectum, Cryptosacciferites pabularis Krassilov et Tekleva, which might have been produced by a gnetalean plant. Pollen grains of this species were found in the guts of Ceroxyela dolichocera Rasnitsyn (Krassilov et al. 2003) in the same locality as Preflosella nathania and a number of other gnetalean plants (e.g., Loricanthus, Aegianthus, and Eoantha). They are trisulcate like Eucommiidites-type pollen which are characteristic for several gnetophyte taxa; however, in contrast to Eucommiidites, pollen grains of Cryptosacciferites pabularis are much larger and have an alveolate infratectum. Besides, the exine is thickened at the equatorial flange and appears there to have protosaccate structure. Thus, these pollen grains show some "degree" of saccus while they look non-saccate in their outer morphology. Scheuring (1978) described similar pollen, Zolerella tricolpata Scheuring, from the Middle Triassic of Switzerland. Only LM photos of Zolerella tricolpata are published but it seems that this pollen also has a thickened exine at the equatorial flange like Cryptosacciferites. Such pollen types can be considered as an intermediate stage between saccate and non-saccate pollen. It is much more difficult to imagine transitional forms between alveolate infratectum and granular or columellalike one though.

Some dispersed pollen taxa known from other localities (e.g., Cladaitina, Ovalipollis) display a similar trend from saccate to non-saccate state (see discussion in Schuurman 1976, Gomankov \& Meyen 1980, Zavattieri \& Gutierrez 2012) that can be interpreted as a transition from one state to another. The exact botanical affinity of Ovalipollis is unknown; pollen grains of Cladaitina-type were found in cones of Cladostrobus included in the Cordaitales (Maheshwari \& Meyen 1975). However, this does not exclude that other gymnosperm groups could produce such pollen grains.

Zavada \& Crepet (1986) considered a possiblity of such a transition in different taxa and concluded that it "may not be as difficult a phylogenetic transition as once thought". Osborn \& Taylor (1994) also discussed saccate pollen with different structure of sacci: this involves not only mono-, bisaccate, transitional or girdling sacci, but also saccus-like structures and caveate angiosperm pollen, endoreticulation nature, ontogenetic and preservation aspects, etc. A special attention should be given to forms with vestigial or ruguloid sacci like Baisianthus ramosus Krassilov et Bugdaeva (Tekleva \& Krassilov 2004). The sacci are small and look like foldings of the exine. Similar structures were documented for some dispersed pollen grains (e.g., Zavada \& Dilcher 1988) and for in situ prepollen of the seed fern Parasporotheca (Millay et al. 1978, Taylor 1982). The infratectum is different in these findings including granular and alveolate types (Zavada \& Dilcher 1988, Tekleva \& Krassilov 2004).

More connections between saccate and non-saccate pollen can be possibly revealed by studying exine ontogeny. Microspores of Juniperus communis L. at tetrad and posttetrad stages have structures resembling vestigial sacci observed in Baisianthus and dispersed pollen figured in Zavada \& Dilcher (1988); however, mature exine of Juniperus lacks these saccus-like structures (S. Polevova, personal observation, see Plate XIII, fig. 2; Plate IX in Gabaraeva et al. 2014). If we look at the exine ultrastructure of Gnetum pollen we also can see a similar structure; in mature Gnetum pollen they are mostly filled with infratectual granules (Tekleva, in press), but it seems that early in the development they sometimes look like vestigial sacci (Meyer, 1977). Careful analysis of these aspects contributes to the correct interpretation of fossil saccate pollen and possible transitional forms between saccate and non-saccate pollen.

\section{Triaperturate pollen and columella-like infratectum}

The trisulcate state in former saccate pollen (like Cryptosacciferites and Zolerella) could have originated from pollen of Ovalipollis-type with a sulcus and two oval or elongate sexinal thinnings (tenuitates) as it was discussed in Pocock \& Jansonius (1969). Another possibility can be imagined as thinning at the the cappa-saccus or cappula-saccus borders in the process of probable saccate - non-saccate transition. The frequent location of lateral furrows in Eucommiidites pollen on distal or proximal poles and commonly seen changing of the ectexine structure at the cappa-saccus border back up this idea. However, as mentioned above, it is much more difficult to imagine how alveolate infratectum could have transformed in granular or columella-like one that we see in other Eucommiidites. Probably trisulcate condition could have developed at least two times in forms like Cryptosacciferites and Zolerella and in Eucommiidites-type pollen. Unfortunately, pollen grains of Cryptosacciferites and Zolerella morphologies have not been found in situ yet and their taxonomic attritubion is pending.

This is a common problem with dispersed pollen grains that are not reliably correlated with any in situ pollen. Dispersed pollen grains can be described within the same genus but include species which are quite different in their morphological or especially ultrastructural details. Some of these genera may in fact include different "piled" plant groups. This is probably the case with genera like Piceapollenites, Falcisporites, Eucommiidites, Ovalipollis and others. For example, dispersed Eucommiidites pollen grains were originally described as a pre-Cretaceous angiosperm (Erdtman 1948). Later, they were shown to be produced by gymnosperms; the three apertures are not located equatorially as in tricolpate angiosperms. Then findings of Eucommiidites pollen in pollen chambers of seeds and in pollen organs have been documented (see review in Tekleva et al. 2006).

At first, such a pollen type seemed to characterize a distinct plant group but accumulating data on different reproductive organs with in situ Eucommïdites pollen as well 
as studies on the exine ultrastructure have shown that at least several plant groups like gnetalean, cycadalean and others produced pollen of this type (see review in Tekleva \& Krassilov 2009).

If this suggestion is true, cycadalean and gnetalean plants might have had at least two pollen morphotypes in common: Eucommiidites- and Cycadopites-types. Modern cycadalean taxa lack Eucommiidites-type pollen and their pollen grains are characterized by an alveolate infratectum. However, it is possible that extinct members of the group were much more diverse in pollen morphology and ultrastructure. Inaperturate pollen grains were reported for Cycandra profusa Krassilov et Delle (Tekleva et al. 2007) and Androstrobus prisma Thomas et Harris (Zavialova \& Van Konijnenburgvan Cittert 2012). Pollen grains extracted from Androstrobus manis Harris (Van Konijnenburg-van Cittert 1971) resemble Chasmatosporites (Batten \& Dutta 1997). Three species of monosulcate Chasmatosporites pollen have been studied by Batten \& Dutta (1997) and they are quite similar in the morphology and exine ultrastructure to gnetophyte pollen of Aegianthus sibiricus Krassilov (figured in Tekleva \& Krassilov 2009). As Chasmatosporites is a dispersed pollen taxon and was not reliably documented in situ, we cannot surely relate Chasmatosporites to Aegianthus sibiricus. A recent study by Zavialova \& Van Konijnenburg-van Cittert (submitted) of the exine ultrastructure of in situ pollen grains of Androstrobus manis has shown that they are distinctly different from Chasmatosporites species studied by Batten \& Dutta (1997).

Amazingly, pollen grains of Androstrobus manis were shown to have a peculiar infratectal type somewhat similar to that described for pollen of Hastystrobus muirii Van Konijnenburg-van Cittert from the same deposits (Van Konijnenburg-van Cittert 1971). Hastystrobus muirii was described as a cycadalean plant (Van Konijnenburg-van Cittert 1971) but in situ pollen grains of Eucommiidites-type were inconsistent with the idea of cycadalean plants. Now, with the recent study on in situ Androstrobus manis pollen the common concept of cycadalean pollen can be enriched. The aperture type of cycadalean pollen thus might have comprised inaperturate, monosulcate, ulcerate, and trisulcate types. The exine ultrastructure was alveolate or rarely granular-columella-like. Thus, such examples warn us not to rely on one character (e.g., pollen of Eucommiidites-type unknown for cycadalean before) in spite of its seemingly high specialization.

\section{CONCLUDING REMARKS}

Based on the similar pollen morphology of Alisporites alimentosus and Preflosella nathania Krassilov \& Bugdaeva (1999) supposed that they could have been produced by the same or closely related species. As Alisporites alimentosus pollen grains were found in the gut of insects from the same locality as Preflosella nathania Krassilov \& Bugdaeva (1999) surmised that "a bisexual structure of the latter was developed as a consequence of entomophily". However, the exine ultrastructure of these species has shown that they were not produced by closely related species. This does not disprobe the conclusion by Krassilov \& Bugdaeva (1999) about correlation of entomophily and bisexual structure of Preflosella reproductive organs but rules out Preflosella as a producer of Alisporites alimentosus pollen. The producer of such pollen is most probably among conifer taxa which are reported to dominate in the Baisa locality (Vachrameev \& Kotova 1977, Bugdaeva 2010).

Studies on in situ pollen are crucial especially in plant groups with a great diversity of pollen morphology and ultrastructure like gnetophytes or peltasperms. Seeming palynological uniformity of some other plant groups might be reconsidered by a careful examination of the exine ultrastructure of their members.

In many cases it is the exine ultrastructure that turns out to be the most important character to distinguish between similar forms or to relate seemingly different pollen (see examples in Tekleva et al. 2006, Zavialova \& Gomankov 2009, Zavialova et al. 2011, Zavialova, this volume, this study). This is the case with the studied material, when similar size and pollen morphology conceal three completely different ultrastructural types (compare Fig. 1A, B, Fig. 2A, and Fig. 3B).

It seems like there were periods of quick evolutional changes ("trying a shot") in different plant organs and there are some extinct taxa having "strange" for us combination of characters (as we see in gnetophytes, Caytoniales and some other groups): so it is difficult to interpret them. This is when we see intermediate forms or some very ususual morphologies which resist common logic of classification. In such cases it is hard to apply our knowledge of what structure can be characteristic of which plant group, which morphologies we should expect in a particular group, and so we should accumulate more factual material on members of the group and prevent extrapolation of established stereotypes over new and understudied findings. For good or for ill these periods of quick changings seem to be short and after such trials we mostly see plant remains that more or less sit well with a common systematics.

\section{ACKNOW LEDGEMENTS}

I am grateful to my late supervisors Prof. N.R. MeyerMelikian and Prof. V.A. Krassilov for a possibility to work on this material and for their valuable advice and discussions. The work was performed at User Facilities Center of M.V. Lomonosov Moscow State University under financial support of Ministry of Education and Science of Russian Federation. The study was partly supported by the grants of the Russian Foundation for Basic Research, project no. 14-04-00044, and by grant of President of RF, no. MK-3156.2014.4.

\section{LITERAT URE CITE D}

Ash, S.R. 1970. Dinophyton, a problematical new plant genus from the Upper Triassic of the South-Western United States. Palaeontology 13(4):646-663.

Ash, S. \& R.J. Litwin 1996. Two new species of the pinnate microsporophyll pramelreuthia from the Upper Triassic of the southwestern United States. American Journal of Botany 83(8):1091-1099.

Axsmith, B.J. \& S.R. Ash 2006. Two rare fossil cones from the Upper Triassic Chinle Formation in Petrified Forest National Park, Arizona, and New Mexico. Museum of Northern Arizona Bulletin 62:82-94.

Axsmith, B.J., E.L. Taylor, T.N. Taylor \& N.R. Cuneo 2000. 
New perspectives on the Mesozoic seed fern order Corystospermales based on attached organs from the Triassic of Antarctica. American Journal of Botany 87:757-768.

Batten, D.J. \& R.J. Dutta 1997. Ultrastructure of exine of gymnospermous pollen grains from Jurassic and basal Cretaceous deposits in Northwest Europe and implications for botanical relationships. Review of Palaeobotany and Palynology 99:25-54.

Bugdaeva, E.V. 2010. New species of Sphenobaiera Florin (Ginkgoales) from the Lower Cretaceous of Transbaikalia. Paleontological Journal 44(10):1240-1251.

Erdtman, G. 1948. Did dicotyledonous plants exist in Early Jurassic time? Förhandlingar, Geologiska Föreningen i Stockholm 70:265-271.

Gabaraeva, N., V. Grigorjeva \& S. Polevova 2014. Sporoderm and tapetum ontogeny in Juniperus communis (Cupressaceae). Connective structures between tapetum and microspores. Review of Palaeobotany and Palynology 206: 23-44.

Gomankov, A.V. \& S.V. Meyen 1980. On the relationships of plant mega- and microfossil assemblages in the Permian of Angaraland. Paleontologicheskii Zhurnal 4:114-122 (in Russian). ГГоманьков А.В., Мейен С.В. 1980. О соотношении комплексов растительных макро- и микрофоссилий в перми Ангариды // Палеонтологический журнац. № 4. С. 114-122].

Gomankov, A.V. \& S.V. Meyen 1986. Tatarian flora (composition and distribution in the Late Permian of Eurasia). Trudy Geologicheskogo Instituta AN SSSR 401: 1-174 (in Russian). [Гоманьков А.В., Мейен С.В. 1986. Татариновая флора (состав и распространение в позАней перми Евразии). Москва: Труды Геологического института АН СССР, вып. 401, Наука. 174 с.].

Gomankov, A.V. \& V.F. Tarasevich 2012. The morphology and ultrastructure of pollen grains of Scutasporites nanuki Utting (Sashiniaceae, Coniferales) from the Permian of the East-European Planform. Paleobotanika 3: 5-11 (in Russian). [Гоманьков А.В., Тарасевич В.Ф. 2012. Морфология и ультраструктура пыльцевых зерен Scutasporites nanuki Utting (Sashiniaceae, Coniferales) из пермских отложений Восточно-Европейской платформы // Палеоботаника. Т. 3. С. 5-11].

Kedves, M. 1994. Transmission electron microscopy of the fossil gymnosperm exines. Juhasz Nyomda, Szeged, 125 pp.

Krassilov, V.A. 1997. Angiosperm origins: morphological and ecological aspects. Pensoft, Sofia, 270 pp.

Krassilov, V.A. 2009. Diversity of Mesozoic gnetophytes and the first angiosperms. Paleontological Journal 43(10): 1272-1280.

Krassilov, V.A. \& S.R. Ash 1988. On Dinophyton - protognetalean mesozoic plant. Palaeontographica 208 (1-3):33-38.

Krassilov, V.A. \& E.V. Bugdaeva 1999. An angiosperm cradle community and new proangiosperm taxa. Acta Palaeobotanica, Supplement 2:111-127.

Krassilov, V.A. \& E.V. Bugdaeva 1982. Achene-like fossils from the Lower Cretaceous of the Lake Baikal area. Review of Palaeobotany and Palynology 36(3-4):279-295.

Krassilov, V.A. \& A.P. Rasnitsyn 1982. Unique find: pollen grains in the gut content of the Early Cretaceous xyelids. Paleonologicheskii Zhurnal 4:83-96 (in Russian). [Красимов В.А., Расницын А.П. 1982. Уникальная находка: пыльца в кишечнике раннемеловых пилильщиков // Палеонтологический журнал. № 4. С. 83-96].

Krassilov, V.A., M.V. Tekleva, N.R. Meyer-Melikyan \& A.P. Rasnitsyn 2003. New pollen morphotype from gut compression of Cretaceous insect, its bearing on palynomorphological evolution and palaeoecology. Cretaceous
Research 24:149-156.

Lazzaro, M.D. 1999. Microtubule organization in germinated pollen of the conifer Picea abies (Norway spruce, Pinaceae). American Journal of Botany 86(6):759-766.

Maheshwari, H.K. \& S.V. Meyen 1975. Cladostrobus and the systematics of cordaitean leaves. Lethaia 8:103-123.

Meyer, N.R. 1977. Comparative morphological studies of sporoderm development and ultrastructure of gymnosperms and primitive angiosperms. Doctoral thesis. Leningrad, 360 pp. (in Russian). [Мейер H.P. 1977. Сравнительные морфологические исследования развития и ультраструктуры спородермы голосеменных и примитивных покрытосеменных. Аисс. на соиск. ... А.б.н.

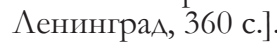

Meyer-Melikyan, N.R., I.Yu. Bovina, Ya.V. Kosenko, S.V. Polevova, E.E. Severova, M.V. Tekleva \& P.I. Tokarev 2004. Atlas of morphology of Asterales (Asteraceae). Palynomorphology and the development of sporoderm in members of the family Asteraceae. KMK, Moscow, 236 pp. (in Russian). [Мейер-Меликян Н.Р., Бовина И.Ю., Косенко Я.В., Полевова С.В., Северова Е.Э., Теклёва М.В., Токарев П.И. 2004. Атлас морфологии астровых (Asteraсеае). Палиноморфология и развитие спородермы преАставителей семейства Asteraceae. Москва: Товарищество научных изданий КМК, 236 с.].

Millay, M.A. \& T.N. Taylor 1974. Morphological studies of Paleozoic saccate pollen. Paleontographica 147: 75-99.

Millay, M.A., D.A. Eggert \& R.L. Dennis 1978. Morphology and ultrastructure of four Pennsylvanian prepollen types. Micropaleontology 24(3):303-315.

Osborn, J.M. 1994. The morphology and ultrastructure of Caytonanthus. Canadian Journal of Botany 72:1519-1527.

Osborn, J.M. \& T.N. Taylor 1993. Pollen morphology and ultrastructure of the Corystospermales: permineralised in situ pollen from the Triassic of Antarctica. Review of Palaeobotany and Palynology 79:205-219.

Pedersen, K.R. \& E.M. Friis 1986. Caytonanthus pollen from the Lower and Middle Jurassic. In: 25 years of geology in Aarbus (J.T. Muller, ed.), pp. 255-267, Geoskrifter 24, Denmark.

Pettitt, J.M. 1985. Pollen tube development and characteristics of the protein emission in conifers. Annals of Botany 56:379-397.

Pigg, K.B., W.C. Davis \& S. Ash 1993. A new permineralized Upper Triassic flora from Petrified Forest National Park, Arizona: a preliminary report. New Mexico Museum of Natural History \& Science Bulletin 3:411-413.

Pocock, S.A.J. \& J. Jansonius 1969. Redescription of some fossil gymnosperm pollen (Chasmatosporites, Marsupipollenites, Ovalipollis). Canadian Journal of Botany 47: 155-165.

Runions, C.J., K.H. Rensing, T. Takaso \& J.N. Owens 1999. Pollination of Picea orientalis (Pinaceae): saccus morphology governs pollen buoyancy. American Journal of Botany 86(2):190-197.

Scheuring, B.W. 1978. Mikrofloren aus den Meridekalken des Mts. San Giorgio (Kanton. Terrsin). Schweizerische Paläontologische Abhandlungen 88:1-119.

Schuurman, W.M.L. 1976. aspects of Late Triassic palynology. 1. On the morphology, taxonomy and stratigraphical/ geographical distribution of the form genus Ovalipollis. Review of Palaeobotany and Palynology 21:241-266.

Taylor, T.N. 1982. Ultrastructural studies of Paleozoic seed fern pollen: sporoderm development. Review of Palaeobotany and Palynology 37:29-53.

Taylor, T.N., M.A.Cichan \& A.M. Baldoni 1984. The ultrastructure of Mesozoic pollen: Pteruchus dubius (Thomas) 
Townrow. Review of Palaeobotany and Palynology 41:319-327.

Taylor, T.N., E.L. Taylor \& M. Krings 2009. Paleobotany. The biology and evolution of fossil plants. Academic Press, San Diego, 1230 pp.

Tekleva, M.V. 2016. Pollen morphology and ultrastructure of several Gnetum species: an electron microscopic study. Plant Systematics and Evolution, in press.

Tekleva, M.V. \& V.A. Krassilov 2004. Sporoderm ultrastructure in Early Cretaceous proangiosperms. Paleontological Journal 38(1):97-102.

Tekleva, M.V. \& V.A. Krassilov 2009. Modern Gnetales and fossil gnetophytes: comparative pollen morphology and ultrastructure. Review Palaeobotany and Palynology 156:130-138.

Tekleva, M.V., V.A. Krassilov, J. Kvaček \& J.H.A. Van Konijnenburg-van Cittert 2006. Eucommiidites: ultrastructure and affinities. Acta Palaeobotanica 46(2):137-155.

Tekleva, M.V., S.V. Polevova \& N.E. Zavialova 2007. On some peculiarities of sporoderm structure in members of the Cycadales and Ginkgoales. Paleontological Journal 41(11):1162-1178.

Townrow, J.A. 1962. On some desiccate pollen grains of Permian to Middle Jurassic age. Grana Palynologica 3(2):13-44.

Townrow, J.A. 1965. A new member of Corystospermaceae Thomas. Annals of Botany 29(115):495-511.

Vachrameev, V.A. \& I.Z. Kotova 1977. Ancient angiosperms and their associated plants from the Lower Cretaceous of Transbaikalia. Paleontologicheskii Zhurnal 4:101109 (in Russian). [Вахрамеев В.А., Котова И.З. 1977. Аревние покрытосеменные и сопутствующие им растения из нижнемеловых отложений Забайкалья // Палеонтологический журнал. №4. С. 101-109].

Van Konijnenburg-Van Cittert, J.H.A. 1971. In situ gymnosperm pollen from the Middle Jurassic of Yorkshire. Acta Botanica Neerlandica 20(1):1-96.

Xuanli, Y., T.N. Taylor \& E.L. Taylor 1995. The corystosperm pollen organ Pteruchus from the Triassic of Antarctica. American Journal of Botany 82(4):535-546.

Zavada, M.S. 1991. The ultrastructure of pollen found in dispersed sporangia of Arberiella (Glossopteridaceae). Botanical Gazzette 152: 248-255.

Zavada, M.S. \& W.L. Crepet 1985. Pollen wall ultrastructure of the type material of Pteruchus africanus, $P$. dubius, and P. papillatus. Pollen et Spores 27:271-276.

Zavada, M.S. \& W.L. Crepet 1986. Pollen grain wall structure of Caytonanthus arberi (Caytoniales). Plant Systematics and Evolution 153:259-264.
Zavada, M.S. \& D.L. Dilcher 1988. Pollen wall ultrastructure of selected dispersed monosulcate pollen from the Cenomanian, Dakota Formation, of central USA. American Journal of Botany 75:669-679.

Zavattieri, A.M. \& P.P. Gutierrez 2012. A new species of Cladaitina Maheshwari et Meyen, 1975 (cordaitalean pollen) from Uppermost Permian deposits of the Famatina range, Central Western Argentina. Revista Brasileira de Paleontologia 15 (2): 125-134.

Zavialova, N.E. 1998. Morphology and ultrastructure of fossil pollen (from Upper Permian deposits of Vyatke river and Lower Jurassic deposits of Western Siberia). PhD thesis. Moscow, 280 pp. (in Russian). [Завьялова Н.Е. 1998. Морфология и ультраструктура ископаемых пыльцевых зерен (из верхнепермских отложений верховий реки Вятка и нижнеюрских отложений ЗапаАной Сибири. Аисс. на соиск. ... к.б.н. Москва. 280 с.].

Zavialova, N.E. 2015. Evolutionary transformations of sporoderm ultrastructure in certain monophyletic lineages of higher plants. Botanica Pacifica 4(2):49-57.

Zavialova, N.E. \& A.V. Gomankov 2009. Occurrence of angiosperm-like ultrastructural features in gymnosperm pollen from the Permian of Russia. Review of Palaeobotany and Palynology 156(1-2): 79-89.

Zavialova, N.E. \& E.V. Karasev 2015. Exine ultrastructure of in situ Protohaploxypinus from a Permian peltasperm pollen organ, Russian Platform. Review of Palaeobotany and Palynology 213:27-41.

Zavialova, N.E. \& J.H.A. Van Konijnenburg-van Cittert 2011. Exine ultrastructure of in situ peltasperm pollen from the Rhaetian of Germany and its implications. Review of Palaeobotany and Palynology 168(1):7-20.

Zavialova, N.E. \& J.H.A. Van Konijnenburg-van Cittert 2012. Exine ultrastructure of in situ pollen from the cycadalean cone Androstrobus prisma Thomas et Harris 1960 from the Jurassic of England. Review of Palaeobotany and Palynology 173:15-22.

Zavialova, N.E., N.R. Meyer-Melikian \& A.V. Gomankov 2001. Ultrastructure of some Permian pollen grains from the Russian platform. In: Proceedings of the IX International Palynological Congress, Houston, Texas, USA, (D.K. Goodman \& R.T. Clarke, eds), pp. 99-114, American Association of Stratigraphic Palynologists Foundation, Houston.

Zavialova, N.E., V.S. Markevich, E.V. Bugdaeva \& S.V. Polevova 2011. The ultrastructure of fossil dispersed monosulcate pollen from the Early Cretaceous of Transbaikalia, Russia. Grana 50:182-201. 